\title{
UNIVARIATE RATIO ANALYSIS DALAM MEMPREDIKSI PERTUMBUHAN LABA PADA PERUSAHAAN TELEKOMUNIKASI BEI
}

\author{
Hendry Saladin, S.E., M.M ${ }^{1)}$ dan Totok Sudiyanto, S.E., M.M ${ }^{2)}$ \\ ${ }^{1}$ Fakultas Ekonomi Universitas PGRI Palembang, \\ email: hendrysaladin43@gmail.com \\ ${ }^{2}$ Fakultas Ekonomi Universitas PGRI Palembang \\ email: totoktajir@yahoo.com
}

\begin{abstract}
ABSTRAK
Penelitian ini bertujuan untuk mengetahui pengaruh Univariate Ratio Analysis Dalam Memprediksi Pertumbuhan Laba Pada Perusahaan Telekomunikasi BEl. Rumusan masalah dalam penelitian ini apakah QR, DER, TAT, ROA berpengaruh terhadap pertumbuhan laba pada perusahaan telekomunikasi yang terdaftar di BEl? Data yang digunakan berupa data sekunder berupa laporan keuangan 5 perusahaan telekomunikasi dengan masa pengamatan tahun 2011 s.d 2015. Model analisis yaitu regresi linear berganda dan melalui pengujian asumsi klasik berupa uji normalitas, uji multikolinearitas, uji autokerelasi dan uji heterokesdatisitas, dengan bantuan SPSS for Windows ver 20.0. Hasil pengujian hipotesis koefisien regresi menunjukkan QR, DER, TAT, ROA tidak berpengaruh signifikan terhadap Pertumbuhan Laba Pada Perusahaan Telekomunikasi BEI.
\end{abstract}

Kata kunci : Quick Ratio, Debt Equity Ratio, Total Aset Turnover, Return on Asset

\section{PENDAHULUAN}

Industri

Telekomunikasi

merupakan salah satu industri yang mendominasi perusahaan-perusahaan yang terdaftar di Bursa Efek Indonesia (BEI). Beberapa perusahaan dalam industri Telekomunikasi tersebut dikelompokkan menjadi beberapa sub kategori industri jasa. Banyaknya perusahaan industri, serta kondisi perekonomian saat ini telah menciptakan suatu persaingan yang ketat antar perusahaan Telekomunikasi. Persaingan dalam industri Telekomunikasi membuat setiap perusahaan semakin meningkatkan kinerja agar tujuannya dapat tetap tercapai. Menurut Salvatore (2005:40) Dalam kasus perusahaan bisnis, tujuannya adalah maksimalisasi laba atau nilai perusahaan atau meminimumkan biaya dengan kendala tertentu. Nilai perusahaan sangat penting karena mencerminkan kinerja perusahaan yang dapat mempengaruhi persepsi investor terhadap perusahaan.
Fungsi seorang manajer keuangan mengambil keputusan investasi, keputusan pendanaan dan keputusan pengelolaan asset. Seorang manajer keuangan harus memahami bagaimana melaksanakan fungsi pembelanjaan secara baik, untuk pertumbuhan perusahaan secara terus menerus. Menurut Martono dan Harjito (2012:4) ada tiga fungsi utama dalam manajemen keuangan yaitu keputusan investasi (investmen Decision), keputusan pendanaan (Financing Decision) dan keputusan pengelolaan aset (Asset Management Decision).

Laporan keuangan sangat diperlukan oleh pemimpin perusahaan atau manajemen sebagai alat untuk pengambilan keputusan lebih lanjut di masa yang akan datang dimana laporan keuangan menggambarkan kondisi keuangan dan hasil usaha suatu perusahaan pada saat tertentu atau jangka waktu tertentu

Dalam penelitian ini kinerja keuangan akan dianlisis dengan Univariate Ratio Analysis yaitu suatu

*) Dosen Tetap Fakultas Ekonomi UPGRI Palembang 
analisis yang menggunakan satu variat. Rasio-rasio yang biasanya digunakan untuk menilai kinerja keuangan perusahaan antara lain rasio likuiditas, solvabilitas, aktifitas dan profitabilitas. Kinerja keuangan dapat diartikan sebagai prospek atau pertumbuhan potensi perkembangan yang baik bagi perusahaan, informasi kinerja keuangan diperlukan untuk menilai perubahan potensial sumber daya ekonomi yang mungkin dikendalikan dimasa depan dan untuk memprediksi kapasitas produksi dari sumber daya yang ada.

Tujuan keputusan keuangan perusahaan yang telah terdaftar di pasar modal adalah untuk meningkatkan nilai perusahaan, diantaranya harga saham (Husnan dan Pudjiastuti, 2012:67). Investor dapat melakukan analisis investasi terhadap pertumbuhan perusahaan melalui Univariate Ratio Analysis yang dimiliki perusahaan yang menjadi alternative investasi.

Laporan keuangan yang sudah dianalisis sangat diperlukan oleh pemimpin perusahaan atau manajemen sebagai alat untuk pengambilan keputusan lebih lanjut di masa yang akan datang dimana laporan keuangan menggambarkan kondisi keuangan dan hasil usaha suatu perusahaan pada saat tertentu atau jangka waktu tertentu, umumnya laporan keuangan merupakan sebuah media informasi yang mencatat dan merangkum segala aktivitas perusahaan serta digunakan untuk melaporkan keadaan dan posisi perusahaan kepada pihak yang berkepentingan, terutama pada pihak kreditur, investor, dan manajemen perusahaan itu sendiri, untuk menggali lebih banyak lagi informasi yang terkandung dalam suatu laporan keuangan maka diperlukan suatu analisis laporan keuangan apabila suatu informasi disajikan dengan benar, informasi itu sangat berguna bagi perusahaan dalam pengambilan keputusan dan untuk mengetahui kinerja keuangan.

Berdasarkan latar belakang yang tersebut diatas, maka penelitian ini dimaksudkan untuk melakukan pengujian lebih lanjut temuan-temuan empiris mengenai analisis rasio-rasio keuangan dalam memprediksi pertumbuhan laba.Hipotesis diajukan variabel $\mathrm{QR}$, DER, TAT, ROA diduga berpengaruh positif dalam memprediksi pertumbuhan laba.

\section{TINJAUAN PUSTAKA \\ Analisa Rasio keuangan}

Analisa rasio adalah suatu metode analisa untuk mengetahui hubungan pos-pos tertentu dalam neraca atau laporan laba rugi secara individu atau kombinasi dari kedua laporan tersebut. Menurut Kasmir (2014: 105) mengatakan bahwa dalam prakteknya analisa kinerja keuangan suatu perusahaan dapat digolongkan menjadi: (1) Rasio neraca yaitu membandingkan angka-angka yang hanya bersumber dari neraca (2) Rasio laporan laba rugi, yaitu membandingkan angka-angka yang hanya bersumber dari laporan laba rugi (3) Rasio antar laporan, yaitu membandingkan angka-angka dari dua sumber baik yang ada di neraca maupun di laporan laba rugi.

Menurut Usman (2003), analisa rasio keuangan dapat dipergunakan sebagai analisa intern bagi manajemen perusahaan untuk mengetahui hasil keuangan yang telah dicapai guna perencanaan yang akan datang dan juga untuk analisa intern bagi kreditur dan investor untuk menentukan kebijakan pemberian kredit dan penanaman modal suatu perusahaan. Analisa rasio keuangan ini dapat dibagi atas dua jenis berdasarkan variate 
yang digunakan dalam analisa, yaitu (Ang, 2010):

\section{Univariate Ratio Analysis}

Univariate Ratio Analysis merupakan analisa rasio keuangan yang menggunakan satu variate didalam melakukan analisa. Contohnya seperti Profit Margin Ratio, Return On Asset (ROA) dan Return On Equity (ROE).

2. Multivariate Ratio Analysis merupakan analisa rasio keuangan yang menggunakan lebih dari satu variate didalam melakukan analisa, seperti Alman's Z-Score dan Zeta Score.

Secara umum, rasio keuangan dapat dikelompokkan menjadi rasio likuiditas, rasio leverage, rasio aktivitas dan rasio profitabilitas (Riyanto, 2014: 330).

1) Rasio Likuiditas

Dalam penelitian ini rasio likuiditas diproksikan dengan QR, karena menurut peneliti sebelumnya, rasio ini yang paling berpengaruh terhadap pertumbuhan laba.

2) Rasio Solvabilitas/Leverage

Dalam penelitian ini rasio leverage diproksikan dengan DER, karena menurut peneliti sebelumnya, rasio-rasio ini yang paling berpengaruh terhadap pertumbuhan laba.

3) Rasio Aktivitas

Dalam penelitian ini rasio aktivitas diproksikan dengan Total Asset Turnover (TAT), karena menurut peneliti sebelumnya, rasio ini yang paling berpengaruh terhadap pertumbuhan laba.

4) Rasio Profitabilitas

Dalam penelitian ini rasio profitabilitas diproksikan dengan ROA karena menurut peneliti sebelumnya, rasio-rasio ini yang paling berpengaruh terhadap pertumbuhan laba.

\section{Pertumbuhan Laba}

Fokus utama laporan keuangan adalah laba. Laba merupakan hasil operasi suatu perusahaan dalam satu periode akuntansi. Informasi laba ini sangat berguna bagi pemilik, investor. Laba yang mengalami peningkatan merupakan kabar baik (good news) bagi investor, sedangkan laba yang mengalami penurunan merupakan kabar buruk (bad news) bagi investor (Wijayati, dkk, 2005).

Laba sebagai suatu alat prediktif yang membantu dalam peramalan laba mendatang dan peristiwa ekonomi yang akan datang. Nilai laba di masa lalu, yang didasarkan pada biaya historis dan nilai berjalan, terbukti berguna dalam meramalkan nilai mendatang. Laba adalah suatu ukuran kepengurusan

(stewardship) manajemen atas sumber daya suatu kesatuan dan ukuran efisiensi manajemen dalam menjalankan usaha suatu perusahaan (Belkaoui, 2007).

\section{Penelitian Terdahulu}

Takarini dan Ekawati (2003)

Hasil Regression Logistic menunjukkan bahwa CLE dan WCTA berpengaruh positif signifikan terhadap perubahan laba di masa mendatang pada tingkat signifikansi sebesar 5\%, sedangkan ROE berpengaruh negative signifikan untuk memprediksi perubahan laba satu tahun ke depan pada tingkat signifikansi sebesar 5\%. Rasio ROA, CLI, STA dan NPM tidak berpengaruh signifikan untuk memprediksi perubahan laba.

Usman (2003) meneliti mengenai "Analisa Rasio Keuangan dalam Memprediksi Perubahan Laba pada Bank-bank di Indonesia", Hasil regresi berganda menunjukkan bahwa tidak ada rasio keuangan yang berpengaruh terhadap Earning After 
Tax (EAT) pada tingkat signifikansi $5 \%$.

Juliana dan Sulardi (2003) melakukan penelitian mengenai manfaat rasio keuangan dalam memprediksi perubahan laba pada 52 perusahaan manufaktur yang terdaftar di BEJ dengan tahun pengamatan 1998-2000. Variabel independen yang digunakan adalah CR, GPM, Operating Profit Margin (OPM), NPM, TAT, ROI, ROE dan Leverage Ratio (LR). Variabel dependen yang digunakan yaitu perubahan laba. Hasil regresi berganda menunjukkan GPM dan OPM berpengaruh positif signifikan terhadap perubahan laba satu tahun kedepan pada tingkat signifikansi $5 \%$, sedangkan TAT dan NPM tidak berpengaruh signifikan terhadap perubahan laba.

Suwarno (2004) meneliti mengenai manfaat informasi rasio keuangan dalam memprediksi perubahan laba pada 162 perusahaan manufaktur yang telah go publik di BEJ dengan periode pengamatan tahun 1998-2002. Hasil analisa regresi berganda menunjukkan bahwa Operating Profit to Profit Before Taxes (OPPBT) Inventory to Working Capital (IWC) dan Net Income to Sales (NIS) berpengaruh positif signifikan terhadap perubahan laba satu tahun ke depan dengan signifikansi kurang dari 5\% sedangkan WCTA, OITL, TAT tidak berpengaruh signifikan terhadap perubahan laba satu tahun kedepan.

Penelitian Ediningsih (2004) berjudul "Rasio Keuangan dan Prediksi Pertumbuhan Laba: Studi Empiris Pada Perusahaan Manufaktur Di BEJ". Hasil analisa regresi berganda menunjukkan bahwa OIS, EBTS dan OITL, berpengaruh positif signifikan terhadap perubahan laba satu dan dua tahun ke depan dengan tingkat signifikansi 5\%. Sedangkan CLI, TLCA, dan NWS berpengaruh negatif signifikan terhadap perubahan laba satu dan dua tahun

Penelitian Syamsudin (2009) Berdasarkan analisa data bahwa variabel CR dan TATO mempunyai pengaruh yang signifikan terhadap perubahan laba, sedangkan untuk variabel DER dan NPM tidak berpengaruh signifikan terhadap perubahan laba.

\section{METODE PENELITIAN Obyek Penelitian}

Penelitian dilakukan pada perusahaan sektor telekomunikasi yang listing (terdaftar) di Bursa Efek Indonesia.

\section{Variabel Penelitian}

Variabel dalam penelitian ini adalah Univariate Ratio Analysis yang terdiri dari Quick Ratio (QR) , Debt to Equity Ratio (DER), Total Asset Turnover (TAT) dan Return on Asset (ROA).

\section{Rancangan Penelitian}

Penelitian ini dirancang sebagai penelitian komparatif. Penelitian komparatif adalah penelitian yang membandingkan sampel penelitian melalui pengujian hipotesis (Sugiono, 2017:119). Periode penelitian adalah tahun 2011 sampai dengan tahun 2015 dimana jangka waktu 5 tahun dapat dianggap periode yang cukup representatif terhadap kebutuhan data.

Populasi adalah perusahaanperusahaan yang terdaftar pada Bursa Efek Indonesia dan terdaftar pada sektor telekomunikasi yang berjumlah 6 perusahaan yaitu PT Bakrie Telecom Tbk., PT XL Axiata Tbk., PT Smartfren Telecom Tbk., PT Indosat Tbk., PT Telekomunikasi Indonesia Tbk., PT. Inovisi Infracom Tbk Sampel berjumlah 5 perusahaan yaitu PT Bakrie Telecom Tbk., PT XL Axiata Tbk., PT Smartfren Telecom Tbk., PT 
Indosat Tbk., PT Telekomunikasi Indonesia Tbk.

Metode yang digunakan dalam penelitian ini adalah purposive random sampling. Pengambilan sampling yang dilakukan dengan sengaja untuk mencapai maksud dan tujuan tertentu, atas dasar kreteria diatas maka akan diambil seluruh atau beberapa sampel yang memenuhi kreteria diatas. Sampel penelitian pada perusahaan telekomunikasi yang ditetapkan pada penelitian ini adalah sebanyak 5 (lima) perusahan yang listing dan konsiten menerbitkan laporan keuangan dari tahun 2011-2015, PT. Inovisi Infracom Tbk dikeluarkan dari sampel sebab tidak menerbitkan laporan keuangan tahun 2015, maka tidak dimasukan dalam tahun pengamatan penelitian ini.

\section{Teknik Pengumpulan Data}

Teknik pengambilan data yang digunakan dalam penelitian ini adalah dokumentasi yaitu berupa dokumendokumen serta catatan selama lima tahun yaitu dari tahun 2011 sampai dengan tahun 2015 yang berupa laporan laba rugi dan laporan neraca perusahaan sektor telekomunikasi yang listing di Bursa Efek Indonesia (BEl).

\section{Teknik Analisis Data}

Penelitian ini menggunakan analisis regresi berganda (Multiple Regression Analysis). Analisis regresi linier suatu model yang kemudian akan diestemasi untuk mengetahui pengaruh rasio keuangan terhadap pertumbuhan laba. Model dalam penelitian ini adalah :

$$
Y_{t}=a+b_{1} X_{1}+b_{2} X_{2}+b_{3} X_{3}+b_{4} X_{4}+e
$$

Dimana :

$\mathrm{Y}_{\mathrm{t}} \quad=$ Pertumbuhan laba

$\mathrm{a}=$ Koefisien konstanta

$\mathrm{b}=$ Koefisien regresi dari masingmasing variabel

$$
\begin{aligned}
\mathrm{X}_{1} & =\mathrm{QR} \\
\mathrm{X}_{2} & =\mathrm{DER} \\
\mathrm{X}_{3} & =\text { TAT } \\
\mathrm{X}_{4} & =\text { ROA } \\
\mathrm{e} & =\text { Koefisien error (variabel } \\
& \text { pengganggu) }
\end{aligned}
$$

\section{Uji Normalitas}

Uji normalitas bertujuan untuk menguji apakah dalam model regresi, variabel dependen dan variabel independen mempunyai distribusi normal atau tidak. Model regresi yang baik, memiliki distribusi data normal atau mendekati normal. Untuk mendeteksi normalitas dapat dilakukan dengan uji statistik. Test statistik yang digunakan antara lain: analisis grafik histogram, normal probability plots dan Kolmogorov Smirnov test (Ghozali, 2011). Pengujian normalitas ini dapat dilakukan melalui analisis grafik dan analisis statistik.

\section{Pengujian Asumsi Klasik Uji Multikolinearitas}

Menurut Ghozali (2011), uji ini digunakan untuk mengetahui apakah terdapat korelasi di antara variabelvariabel independen dalam model regresi tersebut. Untuk mendeteksi ada tidaknya multikoliniearitas dalam model regresi dapat dilihat dari tolerance value atau variance inflation factor (VIF). Sebagai dasar acuannya dapat disimpulkan:

a. Jika nilai tolerance $>0,1$ dan nilai VIF $<10$, maka dapat disimpulkan bahwa tidak ada multikolinearitas antar variabel independen dalam model regresi.

b. Jika nilai tolerance $<0,1$ dan nilai VIF > 10, maka dapat disimpulkan bahwa ada multikolinearitas antar variabel independen dalam model regresi. 


\section{Uji Autokorelasi}

Uji autokorelasi bertujuan untuk menguji apakah model regresi linier ada korelasi antara kesalahan pengganggu pada periode $t$ dengan kesalahan pengganggu pada periode t1 (sebelumnya). Untuk mendeteksi autokorelasi, dapat dilakukan uji statistik melalui uji Durbin-Watson (DW test) (Algifari, 2009).

\section{Uji Heteroskedastisitas}

Uji ini bertujuan untuk menguji apakah dalam model regresi terjadi ketidaksamaan variance dari residual satu pengamatan ke pengamatan yang lain. Jika variance dari residual satu pengamatan ke pengamatan lain tetap, maka disebut Homoskedastisitas dan jika berbeda disebut Heteroskedasitas. Model regresi yang baik adalah yang homokedasitas atau tidak terjadi heteroskedasitas.

\section{Pengujian Hipotesis}

Setelah melakukan pengujian normalitas dan pengujian atas asumsiasumsi klasik, langkah selanjutnya yaitu melakukan pengujian atas hipotesis $1 \quad\left(\mathrm{H}_{1}\right)$ sampai dengan hipotesis $4\left(\mathrm{H}_{4}\right)$. Perhitungan pengujian hipotesis dalam penelitian ini menggunakan SPSS versi 20.0

\section{Uji Statistik F}

Uji $F$ digunakan untuk menguji signifikansi pengaruh QR, DER, TAT dan ROA terhadap pertumbuhan laba perusahaan pertambangan di bursa Efek Indonesia secara simultan.

\section{Uji Statistik t}

Uji $t$ digunakan untuk menguji signifikansi pengaruh QR, DER, TAT dan ROA terhadap pertumbuhan laba pada perusahaan manufaktur di Bursa Efek Indonesia secara individual.

\section{HASIL DAN PEMBAHASAN Uji Normalitas}

Pengujian ini bertujuan untuk mengetahui apakah data terdistribusi normal atau tidak yang dilakukan menggunakan analisis regresi linier. Model regresi yang baik adalah distribusi data masing-masing variabelnya normal atau mendekati normal. Pengujian normalitas dilakukan dengan Uji Kolmogorov Smirnov yang dilakukan terhadap data residual model regresi. Adapun pengujian total sampel data disajikan pada Tabel 1 berikut ini.

Tabel 1

Uji Normalitas

One-Sample Kolmogorov-Smirnov Test

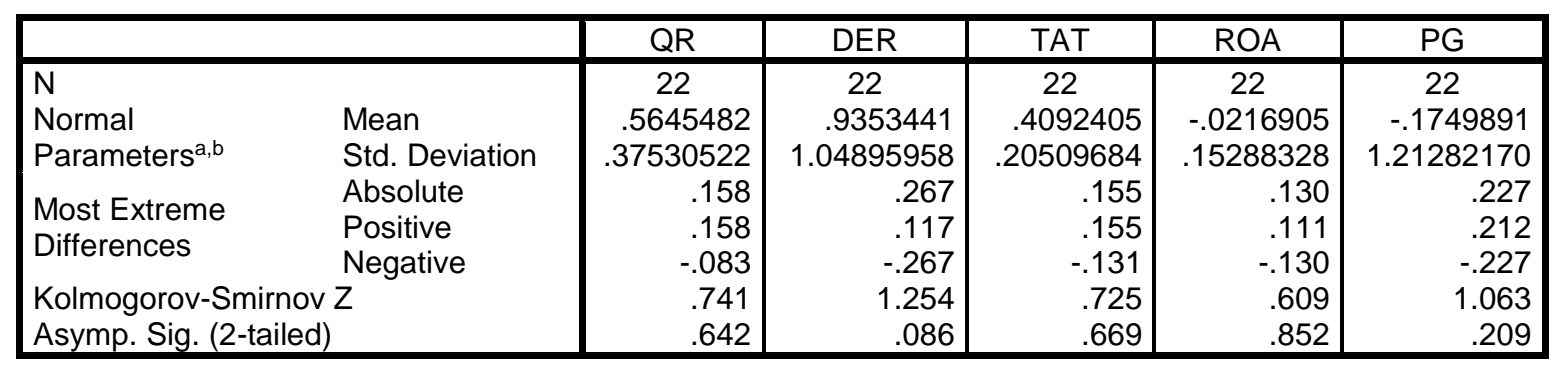

Sumber : Data penelitian yang dioleh dengan SPSS 20 
Penentuan suatu variabel terdistribusi normal atau tidak juga dapat dilihat melalui normal

probability plot yang penyebaran titiktitik variabelnya seharusnya berada tidak jauh di sekitar garis $Y=X$ dan histogram yang membentuk kurva normal (normal curve). Adapun grafik plot penelitian ini terlihat pada Gambar 1 berikut ini.

\section{Gambar 1}

\section{Uji Normalitas}

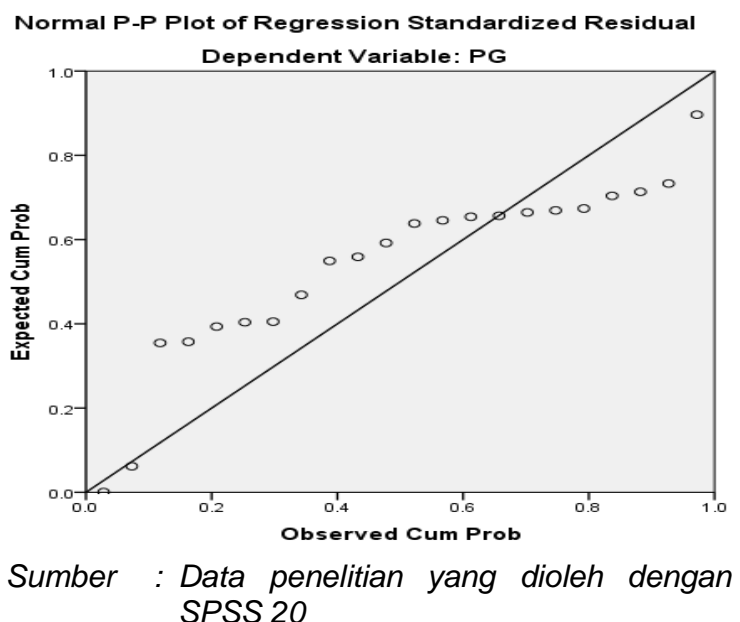

Gambar 1 menunjukan bahwa titik-titik variabel berada di sekitar garis $\mathrm{Y}=\mathrm{X}$ atau menyebar disekitar garis diagonal serta penyebarannya mengikuti arah garis diagonal, ini menunjukkan bahwa data telah terdistribusi normal.

\section{Pengujian Asumsi Klasik}

Uji Asumsi Klasik digunakan untuk menguji, apakah model regresi yang digunakan dalam penelitian ini layak diuji atau tidak. Uji Asumsi klasik digunakan untuk memastikan bahwa multikolinearitas, autokorelasi, dan heteroskedastisitas tidak terdapat dalam model yang digunakan dan data yang dihasilkan terdistribusi normal.

\section{Uji Multikolinearitas}

Uji multikolinearitas

dimaksudkan untuk mengetahui apakah terdapat interkorelasi sempurna antara variabel-variabel independen yang digunakan dalam penelitian ini. Uji ini dilakukan dengan Tolerance Value dan Variance Inflation Factor (VIF). Agar tidak terjadi multikolinearitas, batas Tolerance Value $>0,1$ dan VIF $<10$. Adapun hasil uji multikolinearitas pada penelitian ini dapat dilihat pada Tabel 2.

Tabel 2

Uji Multikolinearitas

\begin{tabular}{|c|c|c|c|}
\hline \multirow{2}{*}{ No } & \multirow{2}{*}{ Variabel } & \multicolumn{2}{|c|}{ Collinearity statistics } \\
\hline & & Tolerance & VIF \\
\hline 1 & QR X1) & .363 & 2.753 \\
\hline 2 & DER (X2) & .928 & 1.078 \\
\hline 3 & TAT (X3) & .264 & 3.781 \\
\hline 4 & ROA (X4) & .249 & 4.014 \\
\hline
\end{tabular}

Berdasarkan Tabel 5.3, tolerance value $>0,1$ dan VIF $<10$, sehingga dapat disimpulkan bahwa keempat variabel independen tersebut tidak terdapat hubungan multikolinearitas dan dapat digunakan untuk memprediksi pertumbuhan laba selama periode pengamatan.

\section{Uji Autokorelasi}

Autokorelasi menunjukkan adanya korelasi antara kesalahan pengganggu pada periode $t$ dengan kesalahan pada periode $\mathrm{t}-1$. Konsekuensinya, variasi sampel tidak dapat menggambarkan variasi populasinya. Akibat yang lebih jauh lagi, model regresi yang dihasilkan tidak dapat digunakan untuk menaksir nilai variabel dependen dari variabel independennya. Untuk mengetahui adanya autokorelasi dalam suatu model regresi, dilakukan pengujian Durbin-Watson (DW) dengan ketentuan yang dapat dilihat pada tabel 3 dan tabel 4 sebagai berikut. 
Tabel 3

Hasil Uji Autokorelasi

Model Summary ${ }^{b}$

\begin{tabular}{|l|c|c|c|c|r|}
\hline Model & $R$ & R Square & $\begin{array}{c}\text { Adjusted R } \\
\text { Square }\end{array}$ & $\begin{array}{c}\text { Std. Error of } \\
\text { the Estimate }\end{array}$ & $\begin{array}{c}\text { Durbin- } \\
\text { Watson }\end{array}$ \\
\hline 1 & $.378^{a}$ & .143 & -.058 & 1.24772081 & 1.709 \\
\hline
\end{tabular}

a. Predictors: (Constant), ROA, DER, QR, TAT

b. Dependent Variable: $P G$

Tabel 4

Autokorelasi

\begin{tabular}{|l|l|r|c|}
\hline \multicolumn{1}{|c|}{ Nilai DW } & \multicolumn{1}{|c|}{ Kesimpulan } & Nilai DW & Kesimpulan \\
\hline$<1$ & Ada autokorelasi & & \\
\hline $1,1-1,54$ & Tanpa kesimpulan & & \\
\hline $1,55-2,46$ & Tidak ada autokorelasi & & Tidak ada Autokorelasi \\
\hline $2,46-2,9$ & Tanpa kesimpulan & & \\
\hline$>2,9$ & Ada autokorelasi & & \\
\hline
\end{tabular}

Sumber : Data penelitian yang dioleh dengan SPSS 20

Berdasarkan hasil perhitungan menggunakan SPSS 20 pada Tabel 4 nilai DW berada diantara 1,55 sampai dengan 2,46, sehingga dapat disimpulkan bahwa tidak terdapat autokorelasi pada persamaan regresi penelitian ini.

\section{Uji Heteroskedasitas}

Pengujian ini bertujuan untuk menguji apakah terjadi ketidaksamaan varian dan residual satu pengamatan ke pengamatan lain dalam model regresi. Model penelitian yang baik adalah homoskedasitas, yaitu varian dan residual satu pengamatan ke pengamatan yang lain hasilnya tetap. Terdapat beberapa cara untuk untuk mendeteksi adanya heteroskedasitas yang menunjukkan bahwa model penelitian kurang layak. Dalam penelitian ini digunakan diagram titik (scatter plot) yang seharusnya titik-titik tersebut tersebar acak agar tidak terdapat heteroskeditas. Adapun hasil uji heteroskeditas dalam penelitian ini disajikan pada Gambar 2 berikut ini.

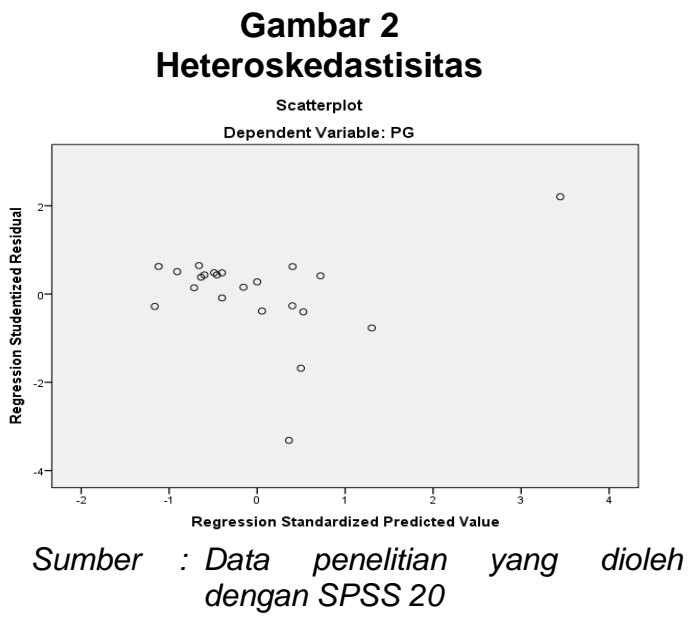

Dengan melihat grafik scatterplot, terlihat titik-titik menyebar secara acak, serta tersebar baik di atas maupun di bawah angka 0 pada sumbu Y. Maka dapat diambil kesimpulan bahwa tidak terdapat gejala heteroskedastisitas pada model regresi yang digunakan.

\section{Univariate Ratio Analysis Dalam Memprediksi Pertumbuhan Laba}

Berdasarkan pengujian asumsi klasik dapat disimpulkan bahwa data yang ada terdistribusi normal, tidak terdapat multikoliniearitas dan heteroskedasitas sehingga memenuhi persyaratan untuk melakukan analisis regresi berganda. 
Koefisien Determinasi $\left(\mathbf{R}^{2}\right)$

Koefisien determinasi $\left(R^{2}\right)$ pada intinya mengukur seberapa jauh kemampuan model dalam menerangkan variabel dependen. Nilai $\mathrm{R}^{2}$ yang kecil berarti kemampuan variabel-variabel independen dalam menjelaskan variabel dependen, terbatas. Nilai yang digunakan adalah adjusted $\mathrm{R}^{2}$ karena variabel independen yang digunakan dalam penelitian ini lebih dari dua buah. Adapun nilai adjusted $\mathrm{R}^{2}$ dari hasil perhitungan menggunakan SPSS 20 terlihat pada Tabel 5.

Tabel 5

Nilai $\mathbf{R}^{2}$

\begin{tabular}{|c|c|c|c|c|}
\hline Model & $\mathrm{R}$ & $\mathrm{R}$ Square & $\begin{array}{c}\text { Adjusted } \mathrm{R} \\
\text { Square }\end{array}$ & $\begin{array}{c}\text { Std. Error of the } \\
\text { Estimate }\end{array}$ \\
\hline 1 & $.378^{\mathrm{a}}$ & .143 & -.058 & 1.24772081 \\
2 & $.359^{\mathrm{b}}$ & .129 & -.016 & 1.22268302 \\
3 & $.341^{\mathrm{c}}$ & .117 & .024 & 1.19841292 \\
4 & $.277^{\mathrm{d}}$ & .077 & .031 & 1.19404755 \\
5 & $.000^{\mathrm{e}}$ & .000 & .000 & 1.21282170 \\
\hline
\end{tabular}

Sumber: Data penelitian yang dioleh dengan SPSS 20

Berdasarkan tabel 5 bahwa nilai korelasi antara variabel independen dengan variabel dependen sebesar 0.277 artinya sedang. Sedangkan nilai $r^{2} \quad$ (Koefisien determinasi) sebesar 0.077 artinya variabel independen dapat menjelaskan variabel dependen sebesar $7,7 \%$ sedangkan sisanya $(100 \%-7.7 \%=92.3 \%) \quad$ dijelaskan oleh faktor lain.

\section{Uji Statistik F}

Berdasarkan hasil regresi dapat diketahui bahwa keempat variabel independen berpengaruh signifikan terhadap pertumbuhan laba. Hal ini dapat dibuktikan dari nilai $F$ yang lebih besar dari tingkat signifikasinya yakni sebesar 0,05 seperti ditunjukkan pada tabel 6 sebagai berikut:

Tabel 6

Hasil Regresi Uji F

\begin{tabular}{|ll|c|c|c|c|c|}
\hline & Model & Sum of Squares & df & Mean Square & F & Sig. \\
\hline 1 & Regression & 4.424 & 4 & 1.106 & .710 & $.596^{\mathrm{b}}$ \\
& Residual & 26.466 & 17 & 1.557 & & \\
& Total & 30.890 & 21 & & & \\
\hline 2 & Regression & 3.980 & 3 & 1.327 & .888 & $.466^{\mathrm{c}}$ \\
& Residual & 26.909 & 18 & 1.495 & & \\
& Total & 30.890 & 21 & & & \\
\hline 3 & Regression & 3.603 & 2 & 1.801 & 1.254 & $.308^{\mathrm{d}}$ \\
& Residual & 27.288 & 19 & 1.436 & & \\
& Total & 30.890 & 21 & & & \\
\hline 4 & Regression & 2.375 & 1 & 2.375 & 1.666 & $.212^{\mathrm{e}}$ \\
& Residual & 28.515 & 20 & 1.426 & & \\
& Total & 30.890 & 21 & & & \\
\hline 5 & Regression & .000 & 0 & .000 &. &. \\
& Residual & 30.890 & 21 & 1.471 & & \\
& Total & 30.890 & 21 & & & \\
\hline
\end{tabular}

Sumber: Data penelitian yang dioleh dengan SPSS 20 


\section{Uji Statistik t}

Pengujian ini bertujuan untuk mengetahui ada atau tidaknya pengaruh satu variabel indipenden terhadap variabel dependen (secara parsial) dengan menganggap variabel independen yang lain konstan. Pengujian ini dilakukan dengan membandingkan nilai signifikansi $t$ yang ditunjukkan oleh Sig dari t pada Tabel 7 dengan tingkat signifikansi yang diambil, dalam hal ini 0,05. Jika nilai Sig dari $\mathrm{t}<0,05$ maka variabel independen berpengaruh terhadap variabel dependen.

Tabel 7

Hasil Regresi Uji t

\begin{tabular}{|c|c|c|c|c|c|c|}
\hline \multirow{2}{*}{\multicolumn{2}{|c|}{ Model }} & \multicolumn{2}{|c|}{ Unstandardized Coefficients } & Standardized & \multirow[t]{2}{*}{$\mathrm{t}$} & \multirow[t]{2}{*}{ Sig. } \\
\hline & & B & Std. Error & Beta & & \\
\hline \multirow{5}{*}{1} & (Constant) & -1.535 & 1.249 & & -1.228 & .236 \\
\hline & QR & .896 & 1.204 & .277 & .744 & .467 \\
\hline & DER & .144 & .269 & .124 & .534 & .600 \\
\hline & TAT & 1.463 & 2.581 & .247 & .567 & .578 \\
\hline & ROA & -5.565 & 3.568 & -.701 & -1.560 & .137 \\
\hline
\end{tabular}

a. Dependent Variable: $P G$

Berdasarkan persamaan diatas, maka coefieficient persamaan regresi yang terbentuk adalah:

$\Delta$ LABA $=-1.535+0.896 Q R+0.144 D E R+$ 1.463TAT - 5.565ROA + e

Hasil perhitungan menggunakan SPSS 20, dapat dilihat dari keempat variabel independen, yaitu variabel $Q R$ $(0,277)$, DER (0.124), TAT (0.247) dan ROA $(-0,701)$ pada saat uji t secara tidak berpengaruh signifikan dalam memprediksi pertumbuhan laba.

\section{Pengujian Hipotesis Hipotesis $1\left(\mathbf{H}_{1}\right)$}

Hipotesis

pertama yang diajukan pada penelitian ini adalah rasio Quick Ratio (QR) berpengaruh positif dalam memprediksi pertumbuhan laba.

Berdasarkan persamaan hasil penelitian diperoleh nilai koefisien regresi untuk variabel $Q R$ sebesar 0,896 dengan nilai signifikansi sebesar 0,744 dimana nilai ini tidak signifikan karena lebih besar dari 0,05. maka hipotesis yang menyatakan bahwa rasio QR berpengaruh positif dalam memprediksi pertumbuhan laba tidak dapat diterima.
Berdasarkan data empiris yang ada dan dari hasil penelitian yang diperoleh, mengindikasikan bahwa naik maupun turunnya QR tidak akan mempengaruhi besarnya pertumbuhan laba. Hasil temuan ini mendukung hasil penelitian dari Usman (2003) yang menyatakan bahwa variabel QR tidak berpengaruh signifikan dalam memprediksi pertumbuhan laba.

\section{Hipotesis 2 (H2)}

Hipotesis kedua yang diajukan pada penelitian ini adalah rasio Debt Equity Ratio (DER) berpengaruh negatif dalam memprediksi pertumbuhan laba.

Berdasarkan persamaan kelima hasil penelitian diperoleh nilai koefisien regresi untuk variabel DER sebesar 0,144 dengan nilai signifikansi sebesar 0,534 dimana nilai ini tidak signifikan karena lebih besar dari 0,05, maka hipotesis kedua yang menyatakan bahwa rasio DER memiliki pengaruh berpengaruh negatif dalam memprediksi pertumbuhan laba tidak dapat diterima.

Berdasarkan data empiris yang 
ada dan dari hasil penelitian yang diperoleh, ini menunjukkan bahwa naik dan turunnya rasio DER tidak mempengaruhi besarnya pertumbuhan laba. Hasil ini sama dengan hasil penelitian yang dilakukan oleh Syamsudin (2009) yang menyatakan bahwa variabel DER tidak berpengaruh signifikan dalam memprediksi pertumbuhan laba.

\section{Hipotesis 3 (H3)}

Hipotesis ketiga yang diajukan pada penelitian ini adalah rasio TAT berpengaruh positif dalam memprediksi pertumbuhan laba .

Berdasarkan persamaan pertama hasil penelitian diperoleh nilai koefisien regresi untuk variabel TAT sebesar 1,463 dengan nilai signifikansi sebesar 0,567 dimana nilai ini tidak signifikan karena lebih besar dari 0,05, maka hipotesis ketiga yang menyatakan bahwa rasio TAT memiliki pengaruh berpengaruh positif dalam memprediksi pertumbuhan laba tidak dapat diterima. Dalam hal ini dapat diargumentasikan bahwa walaupun kondisi perusahaan memiliki aset yang besar, bukan berarti akan memilki nilai penjualan yang besar pula.

Berdasarkan atas hasil pada penelitian ini, variabel TAT menunjukkan pengaruh yang tidak signifikan terhadap pertumbuhan laba. Hal ini mengindikasikan bahwa dengan semakin besarnya rasio TAT tidak akan mempengaruhi besarnya pertumbuhan laba. Hasil temuan ini mendukung hasil penelitian dari penelitian yang dilakukan Suwarno (2004), Juliana dan Sulardi (2003) yang menyatakan bahwa variabel TAT tidak berpengaruh signifikan dalam memprediksi pertumbuhan laba.

\section{Hipotesis 4 (H4)}

Hipotesis keempat Return on Asset (ROA) berpengaruh positif dalam memprediksi pertumbuhan laba.

Berdasarkan hasil penelitian ini diperoleh nilai koefisien regresi untuk variabel ROA sebesar $-5,565$ dengan nilai signifikansi sebesar $-1,560$. Variabel ROA tidak berpengaruh signifikan terhadap pertumbuhan laba berarti naik turunya rasio ROA tidak berpengaruh terhadap besarnya pertumbuhan laba. Variabel ROA dalam penelitian ini mempunyai pengaruh yang negatif dalam memprediksi pertumbuhan laba, hal ini mengindikasikan semakin besarnya rasio $\mathrm{ROA}$ perusahaan, maka prediksi pertumbuhan laba akan semakin menurun.

Hasil ini sama dengan hasil penelitian yang dilakukan oleh Takarini dan Ekawati (2003) yang menyatakan bahwa variabel ROA tidak berpengaruh signifkan positif dalam memprediksi pertumbuhan laba.

\section{KESIMPULAN DAN SARAN}

\subsection{Kesimpulan}

Berdasarkan hasil analisa data dan pembahasan yang telah dilakukan, dapat disimpulkan hal-hal sebagai berikut.

1. Dari empat variabel (yaitu $Q R$, DER, TAT dan ROA) yang diduga berpengaruh terhadap pertumbuhan laba, berdasarkan analisis uji $F$ secara simultan berpengaruh signifikan terhadap pertumbuhan laba, tetapi bila dianalisis dengan uji $t$ secara parsial ternyata keempat variabel tidak berpengaruh signifikan terhadap pertumbuhan laba.

2. Seluruh variabel independen dalam penelitian ini hanya menyumbang $7,7 \quad \%$ dari keseluruhan variabel independen pada nilai adjusted $\mathrm{R}^{2}$. Artinya masih terdapat $92,3 \%$ variabel- 
variabel independen lain yang belum diketahui dan diteliti secara ilmiah, mempengaruhi pertumbuhan laba. Hal ini dikarenakan penelitian ini hanya memperhatikan faktor fundamental perusahaan tanpa memperhatikan kondisi ekonomi makro yang mungkin bisa mempengaruhi pertumbuhan laba.

\subsection{Saran}

Berdasarkan kesimpulan diatas, penulis dapat memberikan saran-saran sebagai berikut:

1. Bagi investor dan calon investor dalam melakukan investasi sebaiknya memperhatikan informasi dalam laporan keuangan, sehingga dapat dijadikan sabagai bahan pertimbangan dalam pengambilan keputusan investasi yang tepat dan menguntungkan.

2. Bagi emiten dan calon emiten sebaiknya mempublikasikan laporan keuangan di media cetak, sehingga informasi yang diperoleh oleh pemakai informasi akan lebih luas dan lebih mudah.

3. Mengingat adanya keterbatasan dalam penelitian ini, maka selanjutnya disarankan untuk melakukan perluasan penelitian dan menggunakan variabel lain yang tidak terdapat dalam penelitian ini, karena pentingnya informasi yang terkandung dalam laporan keuangan.

\section{DAFTAR PUSTAKA}

Algifari, 2009

Analisis Regresi:

Teori, Kasus dan Solusi, Edisi Kedua, BPFE, Yogyakarta.

Ang, Robert. 2010. Buku Pintar: Pasar Modal Indonesia, Mediasoft Indonesia, Jakarta.

Belkaoui, Ahmed. 2007. Teori Akuntansi, Edisi Kelima, Salemba Empat, Jakarta.
Ediningsih, Sri Isworo. 2004. "Rasio Keuangan dan Prediksi Pertumbuhan Laba: Studi Empiris pada Perusahaan Manufaktur di BEJ". Wahana. Vol. 7. No. 1.

Ghozali, Imam. 2011. Aplikasi Analisis Multivariate dengan Program SPSS 19, Badan

Penerbit Universitas Diponegoro, Semarang.

Husnan, Suad dan Enny Pudjiastuti, 2012, Dasar-dasar Manajemen Keuangan, UPP. AMP. YKPN Yogyakarta.

Juliana, Roma Uly dan Sulardi. 2003. "Manfaat Rasio Keuangan Dalam Memprediksi Perubahan Laba Perusahaan Manufaktur ", Jurnal Bisnis \& Manajemen, Vol. 3, No.2.

Kasmir. 2014. Analisis Laporan Keuangan, Cetakan ketiga, Rajagrafindo Persada, Bandung

Martono dan Harjito, D. Agus, 2012, Manajemen Keuangan, Ekorisia, Yogyakarta.

Riyanto, Bambang. 2014. Dasar-dasar Pembelanjaan Perusahaan. Edisi 4, BPFE, Yogyakarta.

Syamsudin dan Ceky Primayuta. 2009. "Rasio Keuangan dan Prediksi Pertumbuhan Laba pada Perusahaan Manufaktur yang Terdaftar di BEI. Benefit Jurnal Manajemen dan Bisnis. Volume 13, Nomor 1. Juni 2009, hlm. 61-69.

Salvatore, Dominick, 2005 Managerial Economics in a Global Economy $4^{\text {th }}$ Edition, Harcourt College Publishers.

Sugiyono. 2017. Metode Menelitian Bisnis, Cetakan ke 25. CV. Alvabeta, Bandung.

Suwarno, Agus Endro, 2004, "Manfaat Informasi Rasio Keuangan Dalam Memprediksi 
Perubahan Laba (Studi Empiris terhadap Perusahaan Manufaktur Go Publik di Bursa Efek Jakarta)". Jurnal Akuntansi dan Keuangan, Vol. 3, No. 2.

Takarini, Nurjanti dan Erni Ekawati. 2003. "Analisis Rasio Keuangan dalam Memprediksi Perubahan Laba Pada Perusahaan Manufaktur di Pasar Modal Indonesia", Ventura, Vol. 6 No. 3.

Usman, Bahtiar. 2003. "Analisis Rasio Keuangan dalam Memprediksi Perubahan Laba pada BankBank di Indonesia", Media Riset Bisnis \& Manajemen, Vol 3 No. 1.

Wijayati, dkk, 2005, "Kemampuan Informasi Keuangan Memprediksi Perubahan Laba", Jurnal Bisnis dan Manajemen, Vol. 5, No. 1. 